Original Article

\title{
NEUROPROTECTIVE EFFECT OF ARTOCARPUS LAKOOCHAEXTRACTAND OXYRESVERATROL AGAINST HYDROGEN PEROXIDE-INDUCED TOXICITY IN SH-SY5Y CELLS
}

\author{
HASRIADI, MATUSORN WONG-ON, PHAKHAMON LAPPHANICHAYAKOOL, NANTEETIP LIMPEANCHOB*
}

Department of Pharmacy Practice and Center of Excellence for Innovation in Chemistry, Pharmacological Research Unit, Faculty of Pharmaceutical Sciences, Naresuan University, Phitsanulok 65000, Thailand

Email: nanteetipl@nu.ac.th

Received: 04 Aug 2017 Revised and Accepted: 21 Sep 2017

\section{ABSTRACT}

Objective: Artocarpuslakoocha Roxb. Is a traditional medical plant native to Southeast Asia and used as a dried aqueous extract so-called puaghaad. Its role (and its major ingredient, oxyresveratrol) as an antioxidant neuroprotectant were explored.

Methods: Differentiated SH-SY5Y neuroblastoma cells in 96-well plates were challenged with $200 \mu \mathrm{M} \mathrm{H}_{2} \mathrm{O}_{2}$ for $4 \mathrm{~h}$ and either Trolox (100 $\mu \mathrm{M}$ ), oxyresveratrol (5-100 $\mu \mathrm{M}$ ), or puaghaad (1.2-25 $\mu \mathrm{g} / \mathrm{ml})$ applied $2 \mathrm{~h}$ before $\mathrm{H}_{2} \mathrm{O}_{2}$ or for $20 \mathrm{~h}$ after $\mathrm{H}_{2} \mathrm{O}_{2}$ washout. Cell viability, mitochondrial function, intracellular ROS, and lipid peroxidation were assessed.

Results: Continuous presence of both $\mathrm{H}_{2} \mathrm{O}_{2}$ and antioxidant reduced mitochondrial function by $~ 50 \%$ but only by $30 \%$ with antioxidant. Sustained $24 \mathrm{~h}$ $\mathrm{H}_{2} \mathrm{O}_{2}$ showed no recoveries with antioxidants. Cell viability was modestly restored when antioxidants accompanied $\mathrm{H}_{2} \mathrm{O}_{2}$ for $4 \mathrm{~h}$ and both washed for another $20 \mathrm{~h}$, but little recovery of mitochondrial function even though antioxidants removed ROS and prevent lipid peroxidation. Antioxidants added for $20 \mathrm{~h}$ after $\mathrm{H}_{2} \mathrm{O}_{2}$ marginally improve mitochondria and modestly restore cell viability, but lipid peroxidation was completely reversed.

Conclusion: These results show that mitochondrial protection was illusive, yet both tested compounds, puaghaad and oxyresveratrol, improved cell viability and especially ROS levels and lipid peroxidation. The potency oxyresveratrol on theredox-sensitive expression of antioxidant enzymes and its pharmacokinetics suggests that oral puaghaad could provide effective protection in transient neurodegenerative disease.

Keywords: Neuroprotection, Oxidative stress, Hydrogen peroxide, Oxyresveratrol, Artocarpuslakoocha

(C) 2017 The Authors. Published by Innovare Academic Sciences Pvt Ltd. This is an open access article under the CC BY license (http://creativecommons.org/licenses/by/4.0/) DOI: http://dx.doi.org/10.22159/ijpps.2017v9i11.21827

\section{INTRODUCTION}

Oxidative stress is one of the causal factorsin neurodegenerative diseases including Alzheimer's disease (AD), Parkinson's disease (PD), ischemia, and especially amyotrophic lateral sclerosis (ALS) which are characterized by excessive ROSs(superoxide, peroxide, hydrogen peroxide and hydroxyl radicals) generated by superoxide dismutase (SOD) $[1,2]$. These ROSs disrupt cell function by peroxidation of lipids and proteins and DNA/RNA oxidation[3-6] Furthermore, high rates of oxidative metabolism in neuronsandthat have limited antioxidantre sources most of which come from astrocytes renders neurons particularly vulnerable[7]. Modest and transient rises in $\mathrm{H}_{2} \mathrm{O}_{2}$ is an important inter-and intracellular physiological signalling mechanism [8]. Nevertheless, $\mathrm{H}_{2} \mathrm{O}_{2}$ is intrinsically stable, but at higher sustained levels it generates highly reactive $\mathrm{OH}$-radicals via the Fenton reaction which oxidizes almost any cell constituent leading to cellular dysfunction $[9,10]$.

Several animal studies show convincing protective effects of antioxidants against ischemia-induced damage including the cell/brain permeanttocoferol analogue, Trolox[11] and the SODmimetic (Mn(III)tetrakis(1-methyl-4-pyridyl)porphyrinpentachloride) reduced lipid peroxidation and DNA fragmentation[12].

Many medicinal plants and their ingredients have also prevent the formation of these oxidized products and in animal studies show brain protection which includes amelioration of pathologies found in $\mathrm{AD}$ and other neurodegenerative pathologies[13]. Artocarpuslakoocha Roxb(monkey fruit)("ma haad" in Thai) is indigenous to South/Southeast Asia, including Thailand where it has been used for hundreds of years as an antihelmintic [15]. It is formulated as a powdered aqueous dried extract and known as puaghaad. Recently, it was shown to beantiviral [14], antiglycation and antioxidant [15]. Oxyresveratrol comprises ahigh content of puaghaad and is likewise neuro protective in vitro and animal studies[16-21],commensurate with its permeability of the bloodbrain barrier (BBB)[22].

Nevertheless, puaghaad is a complex mix of potentially bioactive compounds which collectively may modulate the oxyresveratrol action. Therefore, we sought compare actions of puaghaad against oxyresveratrol in neuroblastoma cells using $\mathrm{H}_{2} \mathrm{O}_{2}$ as the oxidative challenge.

\section{MATERIALS AND METHODS}

\section{Materials}

The following materials were purchased from Sigma (St. Louis, M0): Dulbecco's modified Eagle's medium (DMEM)/F12, 2,2-diphenyl-1picryl-hydrazyl-hydrate (DPPH),2,4,6-tripyridyl-s-trizine (TPTZ), retinoic acid, trichloroacetic acid, thiobarbituric acid, ${ }^{\prime}, 72$. dichlorofluorescein diacetate (DCFH-DA). Fetal bovine serum (FBS), trypsin, and penicillin/streptomycin were purchased from Gibco (Grand Island, NY).Hydrogen peroxide $\left(\mathrm{H}_{2} \mathrm{O}_{2}\right.$ )was purchased from Merck KGaA (Darmstadt, Germany). 2,3-Bis-(2-methoxy-4-nitro-5sulfophenyl)-2H-tetrazolium-5-carboxanilide (XTT) assay kit was purchased from Roche Diagnostics (Mannheim, Germany).

Hardwood aqueous extract of $A$. lakoochaso called puaghaad (PH) was obtained from Origin Plant Co., Ltd (Bangkok, Thailand).

\section{Puag-haadoxyresveratrol content}

A $20 \mu \mathrm{l}$ sample of puaghaad $(1 \mathrm{mg} / \mathrm{ml}$ in DMSO) was injected into a Shimadzu LC-20AT liquid chromatograph equipped with a SPD-20A UV detector, a Ultra HPLC column (250 x $4.60 \mathrm{~mm}$ ) with C18 column packing, $5 \mu \mathrm{m}$ particle size; isocratic elution by methanol $/ \mathrm{H}_{2} \mathrm{O}$ (35:65, flow rate $0.8 \mathrm{ml} / \mathrm{min}$. Peaks were integrated at $254 \mathrm{~nm}$. Puaghaad was assigned by retention time of oxyresveratrol $17 \mathrm{~min}$ and calibrated using $2.5-250 \mu \mathrm{g} / \mathrm{ml}$ oxyresveratrol. 


\section{SH-SY5Y cell culture preparation}

SH-SY5Y cells were cultured in DMEM/F-12 containing L-glutamine, $10 \%$ FBS, $0.01 \%$ penicillin-streptomycin. Cells (3-10 passage) stored in liquid $\mathrm{N}_{2}$ and plated out at $1 \times 10^{6}$ cells $/ \mathrm{cm}^{2}$ into $75 \mathrm{~cm}^{3}$ flasks and grown to confluence at $37^{\circ} \mathrm{C}$ in a humidified atmosphere of $95 \%$ air and $5 \% \mathrm{CO}_{2}$. Cells were passaged $<30$ times to ensure cell uniformity and reproducibility then re-seeded into 96-well plates at 20,000 cells/well for $24 \mathrm{~h}$ at $37^{\circ} \mathrm{C}$. They were differentiated with low serum culture medium $(2 \%$ FBS $)$ containing retinoic acid $(10 \mu \mathrm{M})$ for 6 dbefore use. The medium $(100 \mu \mathrm{l})$ was refreshed at days 3 and 6[23].

\section{$\mathrm{H}_{2} \mathrm{O}_{2}$-induced oxidative stress in SH-SY5Y cells}

The experiments used $\mathrm{H}_{2} \mathrm{O}_{2}(200 \mu \mathrm{M})$ as the oxidizing agent and cell protection examined using Trolox $(100 \mu \mathrm{M})$, oxyresveratrol (5$100 \mu \mathrm{M})$ and puaghaad $(1.25-25 \mu \mathrm{g} / \mathrm{ml})$ all added in $100 \%$ DMSO (final DMSO concentration $<0.01 \%$ ). Three protocols were used where $\mathrm{H}_{2} \mathrm{O}_{2}$ was present for 4 or $24 \mathrm{~h}$, and the cell protectants present before, during, or after $\mathrm{H}_{2} \mathrm{O}_{2}$. Protocols are shown in fig. 2-4.

\section{Cell viability measured by lactate dehydrogenase (LDH) activity}

After treatment, $50 \mu \mathrm{l}$ of the medium was aspirated and place into a new 96 -well plate and $0.3 \mathrm{mmol} \mathrm{NADH}$ and $3 \mathrm{mmolpyruvates}$ added. The absorbance was then measured at $340 \mathrm{~nm}$ at $0,5,10,15$ and 20 $\min [23]$.

\section{Determination of mitochondrial metabolic activity}

According to the kit instructions, XTT solution was added to the remaining culture cells and the orange formazan measured by absorbance at $460 \mathrm{~nm}$ produced by the mitochondrial enzyme. This gives an estimate of mitochondrial respiratory chain function.

\section{Determination of intracellular ROS}

Other differentiated SH-SY5Y neuroblastoma cells in a 96-well black plate were treated with DCFH-DA $(5 \mu \mathrm{M})$ for $30 \mathrm{~min}$. The culture medium was removed, and cells washed with PBS prior. DCFH-DA penetrates cells, then hydrolyzed by intracellular esterases to DCFH which is oxidized to fluorescent diclorofluorescein in the presence of ROS. The fluorescence was excited at $485 \mathrm{~nm}$ excitation and emission measured at $530 \mathrm{~nm}$ in a microplate reader[23].

\section{Lipid peroxidation by thiobarbituric acid reactive substances (TBARs) assay}

For other cells, the end of treatment, $100 \mu \mathrm{l}$ of TBARs reagent containing $0.4 \% \mathrm{TBA}, 1.4 \% \mathrm{TCA}$, and $8 \% \mathrm{HCl}(1: 2: 1)$ were added to each well and cells resuspended. The mixtures were incubated at $90^{\circ} \mathrm{C}$ for $1 \mathrm{~h}$, cooled to room temperature, and fluorescence was measured at excitation at $535 \mathrm{~nm}$ and emission at $595 \mathrm{~nm}$ wavelengths[24].

\section{DPPH scavenging assay}

Free radical scavenging activity was measured by mixing $0.2 \mathrm{mmol}$ DPPH assay and test compounds at various concentrations, incubated at room temperature for $30 \mathrm{~min}$ in the dark, and absorbance measured at $515 \mathrm{~nm}$ wavelength[24].

\section{Reduction by ferric reducing antioxidant power (FRAP) assay}

This assay depends on $\mathrm{Fe}^{3+}$ reduction to $\mathrm{Fe}^{2+}$. FRAP reagent (comprising 10:1:1 of $3 \mathrm{mmol}$ acetate buffer $(\mathrm{pH} 3.6), 10 \mathrm{mmol}$

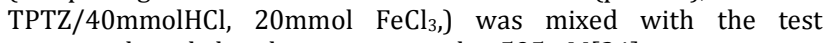
compounds and absorbance measured at $595 \mathrm{nM}$ [24].

\section{Statistical analysis}

Data from all assays are expressed as the mean \pm SEM (standard error of themean). The data were analyzed by analysis of variance (ANOVA)and the Prism program (GraphPad Software Inc). Differences were considered to be significant when $p$ value $\leq 0.05$.

\section{RESULTS AND DISCUSSION}

Oxyresveratrol content in puag-haad

Hardwood aqueous extract of A. lakoocha(puaghaad) used in this study contained $64.68 \%$ oxyresveratrol by HPLC (fig. 1).
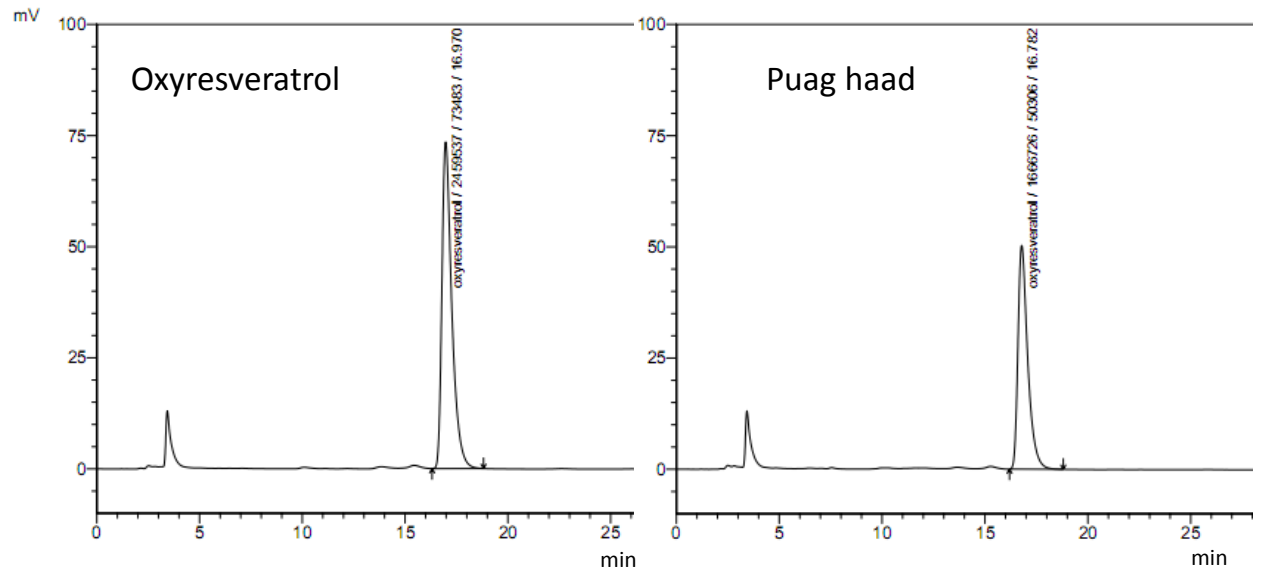

Fig.1: HPLCchromatogram of oxyresveratrol and $A$. lakoochaextract (puaghaad) at RT=17 min with detector response at $254 \mathrm{~nm}$

\section{Acute and chronic $\mathrm{H}_{2} \mathrm{O}_{2}$ action}

Differentiated SH-SY5Y neuroblastomacells were exposed to 200 $\mu \mathrm{M} \mathrm{H} \mathrm{H}_{2} \mathrm{O}_{2}$ for $4 \mathrm{~h}$ to emulate acuteoxidative stress, and $24 \mathrm{~h}$ representing a chronic challenge (fig.2A).

Acutely, $\mathrm{H}_{2} \mathrm{O}_{2}$ clearly depressed formazan production (XTT assay) indicative of compromised mitochondrial energy feed through the electron transport chain and oxidative phosphorylation (fig.2C).This depression was manifest at $4 \mathrm{~h}$ and continued through to $24 \mathrm{~h}$.

With the continued presence of Trolox, oxyresveratrol, orpuaghaad (containing $100 \mu \mathrm{M}$ oxyresveratrol by analysis) could partially rescue mitochondrial function (at $4 \mathrm{~h}$ ) but failed to do so after24hof chronic $\mathrm{H}_{2} \mathrm{O}_{2}$ treatment (fig.2C).
Cell viability measured by LDH release into the medium appeared preserved after $4 \mathrm{~h}$ of $\mathrm{H}_{2} \mathrm{O}_{2}$, but succumbed to $24 \mathrm{~h}$ of exposure (fig.2B). None of the anti-oxidant treatments was able to rescue the cells. $\mathrm{H}_{2} \mathrm{O}_{2}$-induced oxidative stress reduced glutathione level [25], induced DNA damage and apoptosis in cultured cells [26]. $\mathrm{H}_{2} \mathrm{O}_{2}$ action is accompanied by mitochondrial depolarization, aggregation, and cytochrome C release [27], and increased MAPK and p38 [28] in other cells and SH-SY5Y cells[29].

Our proposition that electron chain transport disrupted is confirmed by inhibition of NADH-Co Qreductase and ATP synthase [30]. All these factors are associated with apoptosis confirmed in our experiments with $24 \mathrm{~h}$ exposures but most authors confined protocols to short treatments and unable to assess long-term consequences. 
A.

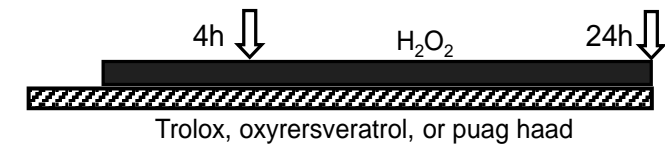

B.

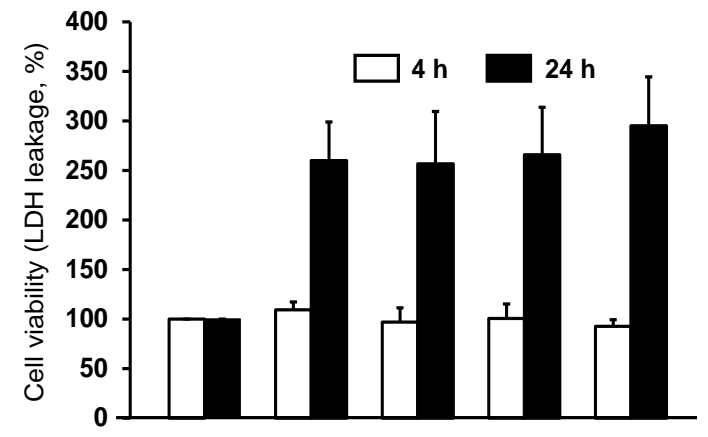

c.

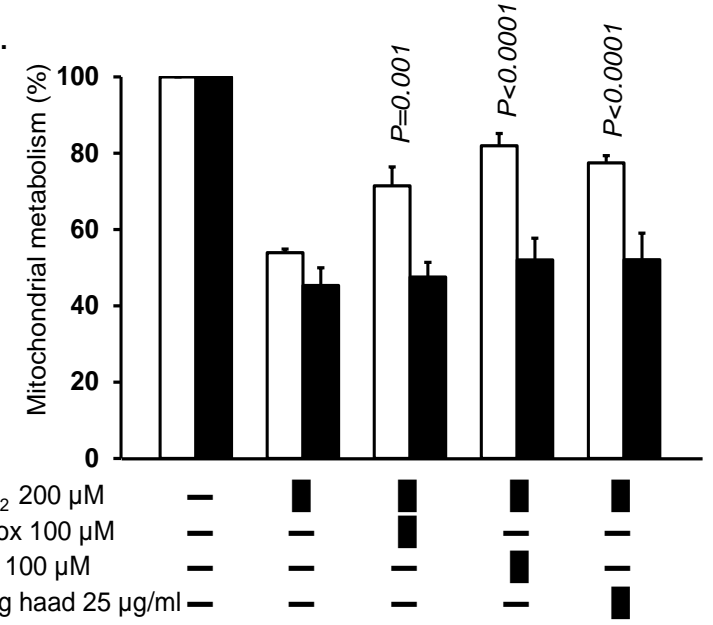

Fig.2:(A) Protocol showing interventions, either nothing, trolox, oxyresveratrol (Oxy), or puaghaad added to cultured SH-SY5Y cells for $2 \mathrm{~h}$ followed by addition of $\mathrm{H}_{2} \mathrm{O}_{2}$ for a further $24 \mathrm{~h}$. The arrows denote measurement times. (B) Changes in cell integrity using LDH leakage into the culture medium. (C) Effects on cell mitochondrial metabolism indicated by the XTT assay. Values are expressed as means \pm SEM of 5 (B) or 6 samples(C). The $p$ values refer to differences compared to $\mathrm{H}_{2} \mathrm{O}_{2}$ treatmentalone

\section{No neuroprotectionby oxyresveratrol and puaghaad}

To show whether the late $(24 \mathrm{~h})$ cellular demise is already set in train by the early $\mathrm{H}_{2} \mathrm{O}_{2}$ challenge, we used a protocol where both the challenge and interventions were removed after $4 \mathrm{~h}$ (fig.3A).Now, cell viability was poor even though at $4 \mathrm{~h}$ exposure to $\mathrm{H}_{2} \mathrm{O}_{2}$ (fig.2B) it had been fully intact. This implies that following $4 \mathrm{~h}$ pathological changes had already begun which only became manifest after a further $20 \mathrm{~h}$. Trolox, oxyresveratrol, and puaghaadcould partly prevent this demise, although doseresponse of both tested compounds were not clearly demonstrated (fig.3B).

The $4 \mathrm{~h} \mathrm{H}_{2} \mathrm{O}_{2}$ exposure left mitochondrial function depressed (fig.2C) and with $20 \mathrm{~h}$ of washout, this dysfunctional state had persisted (fig.3C).Furthermore, this state could not be rescued by antioxidant treatments.

\section{Oxidative stress}

To verify that oxidative species were present $20 \mathrm{~h}$ after $4 \mathrm{~h}$ in $\mathrm{H}_{2} \mathrm{O}_{2}$ treatment, we measured ROSs by probing with DCFH. There was clearly elevated oxidizing species present that was completely neutralized by Trolox, and dose-dependently by oxyresveratrol and puaghaad (fig. 3D). Since $\mathrm{H}_{2} \mathrm{O}_{2}$ is highly diffusible across the plasma membrane, it would have rapidly washed out of cells. But clearly, oxidizing species remained such as $\mathrm{OOH}^{-}, \mathrm{O}^{-2-}$, and $\mathrm{ONOO}^{-}$whose charge would keep them trapped in the cytosol, or that sustained damage has activated peroxisomal enzymes [31], and disrupted the mitochondrial electron transport chain generating $0^{-2} \cdot[32]$.

Important victims of ROSs are polyunsaturated fatty acids which form multiple reactive intermediates and fragments including dialdehydes. $\mathrm{H}_{2} \mathrm{O}_{2}$ modestly increased levels of reactive malonyldialdehyde and Trolox, oxyresveratrol, and puaghaad suppressed this lipid peroxidation levels lower than the baseline (fig. 3E). This suggests that control cells are already oxidatively stressed/auto-oxidized, commensurate with low antioxidant capacity and high glucose concentrations of serum-free media.

All concentrations of oxyresveratrol and puaghaad were equally effective as Trolox.
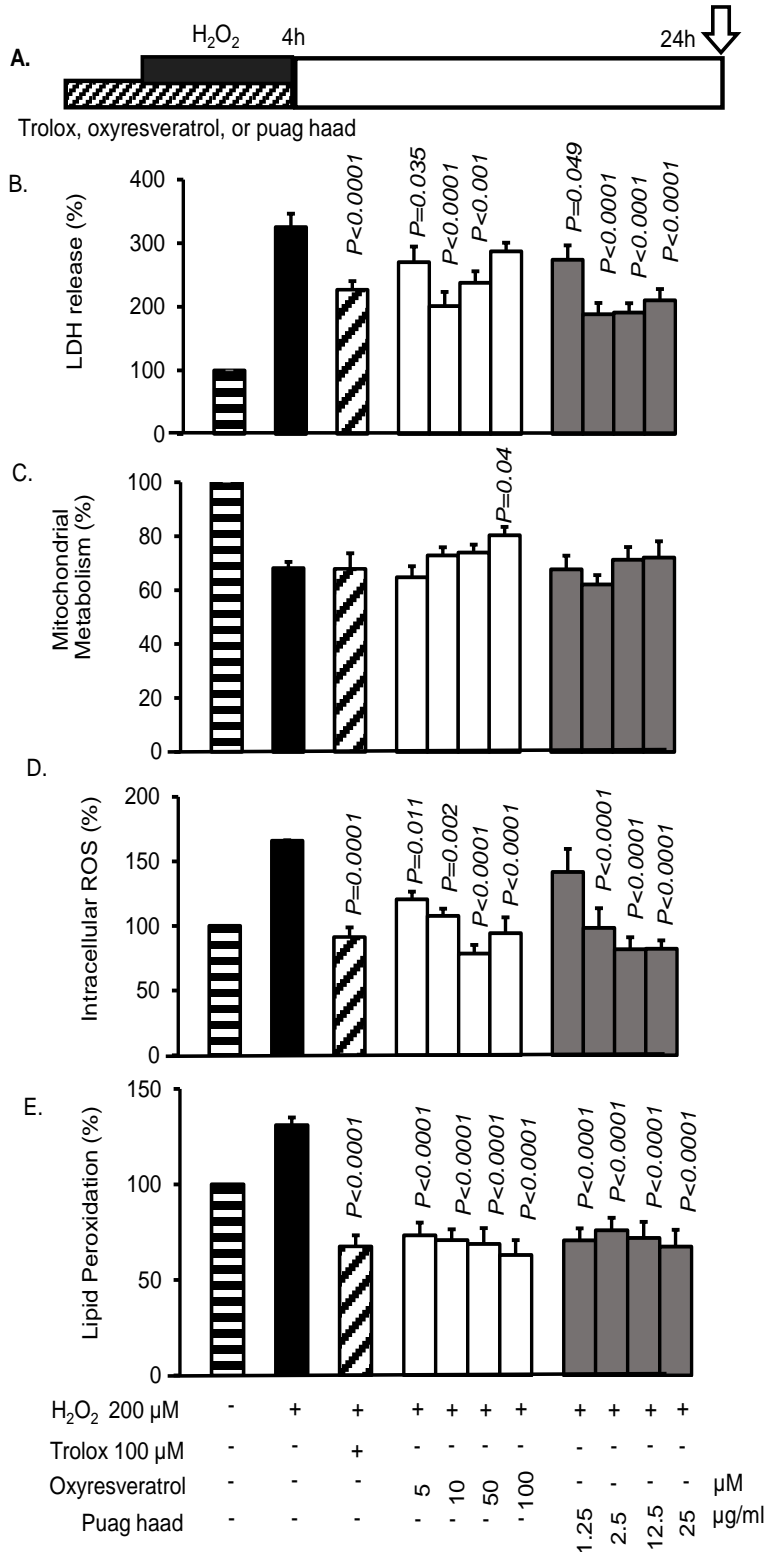

Fig.3: (A) Protocol showing SH-SY5Y cells treated with Trolox, oxyresveratrol or puaghaad (2h) followed by $\mathrm{H}_{2} \mathrm{O}_{2}$ for another $4 \mathrm{~h}$. Then antioxidants and $\mathrm{H}_{2} \mathrm{O}_{2}$ were washed out for another $20 \mathrm{~h}$ and the following measures made: (B) Cell viability measured as LDH activity, (C) Mitochondrial function, (D) Intracellular ROS generation, (E) Cell lipid peroxidation by malonyldialdehyde production. Values are expressed as means \pm SEM of 6 experiments. Thep-values compared to $\mathrm{H}_{2} \mathrm{O}_{2}$ alone (black bar) 


\section{Post-treatment with antioxidants}

In the next series of experiments, antioxidants were added during $20 \mathrm{~h}$ washout period following the $4 \mathrm{~h} \mathrm{H}_{2} \mathrm{O}_{2}$ challenge (fig.4A). For both LDH leakage and mitochondrial hypofunction, none of the antioxidant interventions had much influence on recovery (fig.4B,C). But for malonyldialdehydes all three anti-oxidants were highly effective (fig.4D).

Mitochondrial function showed little restoration byany protocolespecially for Trolox which was designed for mitochondrial function. However, our protocol had 20\% oxygen and $20 \mathrm{mmol}$ glucose present to feed into an uncoupled electron transport chain thereby generatingexcessive superoxide. Even in normally perfused brain oxygen and substrate would be more limiting. All the antioxidants were effective reducing agents for peroxidated lipids irrespective of protocol and concentration. Trolox easily partitions into membranes while resveratrol at least bindsonto membranes and their extracellular and cytosolic concentrations have less influence on thefunction as reflected by oxyresveratrol action irrespectiveof concentration. Thus, the antioxidants are well placed to efficiently scavenge peroxidated fragments before running riot in the cytosol.

For polyphenols, oral oxyresveratrol bioavailability is relatively high achieving $2 \mu \mathrm{M}$ in rat plasma[33]which in humans would need an oral dose $\sim 500 \mathrm{mg}$ by allometric scaling. This is within the range of our lowest dose $(5 \mu \mathrm{M})$ that produced antioxidation. While blood-brain barrier permeability to oxyresveratrol is very low, this is greatly increased during ischemic brain damage achieving $\sim 1 \mu \mathrm{M}[22]$ and fostering repair[18]. However, $5 \mu \mathrm{M}$ would have little impact compared to the totalplasma antioxidant capacity of $\sim 0.5 \mathrm{mmol}[34]$.Furthermore, it is below the IC50 by the DPPH assay (table 1). At these lower concentrations, a more plausible mechanism of oxyresveratrol antioxidant action is through increased expression of endogenous antioxidant enzymes via their transcription factors, Nrf-2 [35], and FOX03a [36]. Ultimately, these enzymes are trafficked to sources of particular ROSs where they are most effective. In contrast, Trolox appears to need higher concentrations than used here thus likely to be a directly acting antioxidant against $\mathrm{H} 2 \mathrm{O} 2$ and other ROSs [37].
A.

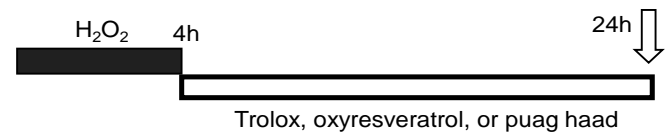

B.
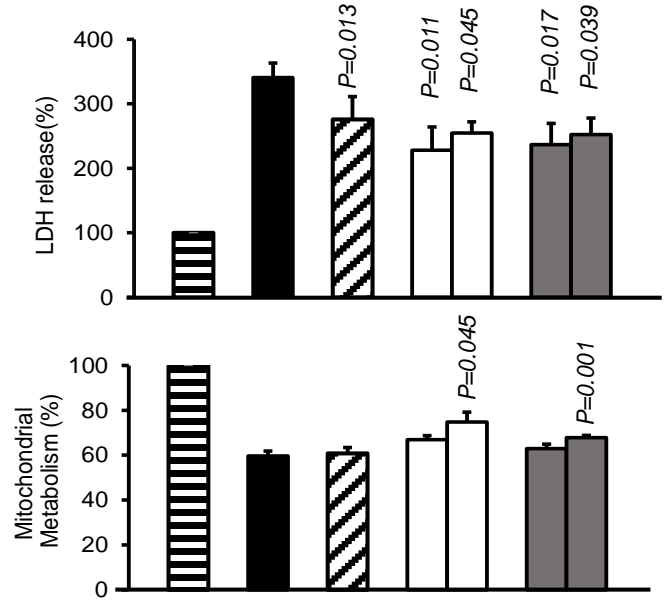

D.

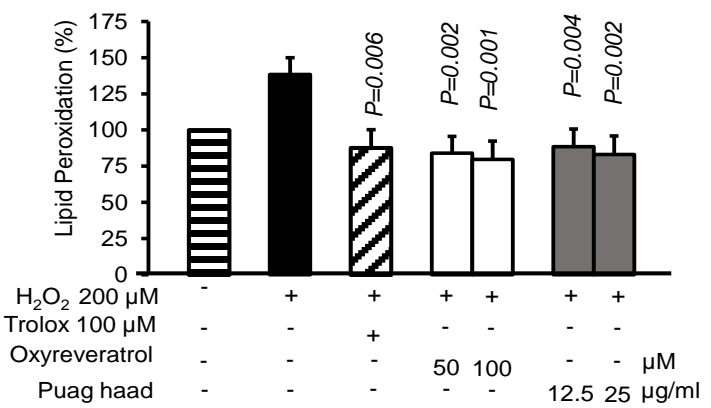

Fig.4: (A) Cells were treated with $200 \mu \mathrm{M} \mathrm{H}_{2} \mathrm{O}_{2}$ for $4 \mathrm{~h}$ and the medium changed for trolox, oxyresveratrolor puaghaadfor 20 h. (B-D) the measurements were as in fig. 3 . The $p$-values compared with $\mathrm{H}_{2} \mathrm{O}_{2}$ without anti-oxidant post treatment

Table 1: Antioxidant activities of oxyresveratrol and puaghaad

\begin{tabular}{lll}
\hline Compounds & DPPH scavenging capacity $\left(\right.$ IC $\left._{\mathbf{5 0}}\right)$ & FRAPFe $^{2+}$ concentration \\
\hline Oxyresveratrol & $38.1 \mu \mathrm{M}$ & $11.2 \mu \mathrm{M}($ at $100 \mu \mathrm{M}$ oxyresveratrol) \\
Puaghaad & $9.3 \mu \mathrm{g} / \mathrm{ml}$ & $12.8 \mu \mathrm{M}$ (at $37.78 \mu \mathrm{g} / \mathrm{mlpuaghaad})$ \\
Trolox & $55.3 \mu \mathrm{M}$ & $8.2 \mu \mathrm{M}($ at $100 \mu \mathrm{M}$ Trolox $)$ \\
\hline
\end{tabular}

Note: $37.78 \mu \mathrm{g} / \mathrm{mlpuaghaad}$ containsoxyresveratrol equivalent to $100 \mu \mathrm{M}$.

\section{CONCLUSION}

These results suggest that both oxyresveratroland oxyresveratrolcontaining puaghaad provides protection of SH-SY5Y neuroblastoma cells against $\mathrm{H}_{2} \mathrm{O}_{2}$ oxidant toxicity and that oxyresveratrol pharmacokinetics suggests that it may offer protection against neuroprotective diseases.

\section{ACKNOWLEDGEMENT}

The authors thank Dr. Norman Scholfield for help in manuscript preparation. Hasriadi was supported by a Naresuan University ASEAN Scholarships.

\section{AUTHOR CONTRIBUTION}

Hasriadi conducted and analyzed most of the results.

Matusorn Wong-On developed and analyzed oxyresveratrol content in puaghaad.

PhakhamonLapphanichayakool developed a test method of $\mathrm{H}_{2} \mathrm{O}_{2}$ induced neuronal toxicity.
Nanteetip Limpeanchob supervised, evaluated, and summarized overall results.

\section{CONFLICT OF INTERESTS}

Declared none

\section{REFERENCES}

1. Andersen JK. Oxidative stress in neurodegeneration: cause or consequence? Nat Med 2004;10 Suppl:S18-25.

2. Kim GH, Kim JE, Rhie SJ, Yoon S. The role of oxidative stress in neurodegenerative diseases. Exp Neurobiol 2015;24:325-40.

3. Granold M, Moosmann B, Staib-Lasarzik I, Arendt T, del Rey A, Engelhard $\mathrm{K}$, et al. High membrane protein oxidation in the human cerebral cortex. Redox Biol 2015;4:200-7.

4. Montine TJ, Neely MD, Quinn JF, Beal MF, Markesbery WR, Roberts LJ, et al. Lipid peroxidation in aging brain and alzheimer's disease. Free Radical Biol Med 2002;33:620-6.

5. Mullaart E, Boerrigter METI, Ravid R, Swaab DF, Vijg J. Increased levels of DNA breaks in thecerebral cortex of Alzheimer's disease patients. Neurobiol Aging 1990;11:169-73. 
6. Lovell MA, Markesbery WR. Oxidatively modified RNA in mild cognitive impairment. Neurobiol Dis 2008;29:169-75.

7. Marcus DL, Thomas C, Rodriguez C, Simberkoff K, Tsai JS, Strafaci $\mathrm{JA}$, et al. Increased peroxidation and reduced antioxidant enzyme activity in Alzheimer's disease. Exp Neurol 1998;150:40-4.

8. Rhee SG. Redox signalling: hydrogen peroxide as anintracellular messenger. Exp Mol Med 1999;31:53-9.

9. Park HR, Lee H, Park H, Jeon JW, Cho WK, Ma JY. Neuroprotective effects of Liriope platyphylla extract against hydrogen peroxideinduced cytotoxicity in human neuroblastoma SH-SY5Y cells. BMC Complementary Altern Med 2015;15:171.

10. Zhang S, Ye J, Dong G. Neuroprotective effect of baicalein on hydrogen peroxide-mediated oxidative stress and mitochondrial dysfunction in PC12 cells. J Mol NeurosciMN 2010;40:311-20.

11. Gupta S, Sharma SS. Neuroprotective effects of trolox in global cerebral ischemia in gerbils. Biol Pharm Bull 2006;29:957-61.

12. Sharma SS, Gupta S. Neuroprotective effect of MnTMPyP, a superoxide dismutase/catalase mimetic in global cerebral ischemia is mediated through reduction of oxidative stress and DNA fragmentation. Eur J Pharmacol 2007;561:72-9.

13. Akhondzadeh S. Herbal medicines in the treatment of psychiatric and neurological disorders. In: L'Abate L. editor. Low-cost approaches to promote physical and mental health: theory, research, and practice. New York, NY: Springer New York; 2007. p. 119-38.

14. Likhitwitayawuid K, Sritularak B, Benchanak K, Lipipun V, Mathew J, Schinazi RF. Phenolics with antiviral activity from Millettia erythrocalyx and Artocarpus lakoocha. Nat Prod Res 2005;19:177-82.

15. Povichit N, Phrutivorapongkul A, Suttajit M, Leelapornpisid P. Antiglycation and antioxidant activities of oxyresveratrol extracted from the heartwood of Artocarpus lakoocha Roxb. Maejo Int J Sci Technol 2010;4:454-61.

16. Weber JT, Lamont M, Chibrikova L, Fekkes D, Vlug AS, Lorenz P, et al. Potential neuroprotective effects of oxyresveratrol against traumatic injury. Eur J Pharmacol 2012;680:55-62.

17. Ban JY, Jeon SY, Nguyen TT, Bae K, Song KS, Seong YH. Neuroprotective effect of oxyresveratrol from Smilacis chinae rhizome on amyloid Beta protein (25-35)-induced neurotoxicity in cultured rat cortical neurons. Biol Pharm Bull 2006;29:2419-24.

18. Andrabi SA, Spina MG, Lorenz P, Ebmeyer U, Wolf G, Horn TF. Oxyresveratrol (trans-2,3',4,5'-tetrahydroxystilbene) is neuroprotective and inhibits the apoptotic cell death in transient cerebral ischemia. Brain Res 2004;1017:98-107.

19. Lorenz P, Roychowdhury S, Engelmann M, Wolf G, Horn TF. Oxyresveratrol and resveratrol are potent antioxidants and free radical scavengers: effect on nitrosative and oxidative stress derived from microglial cells. Nitric Oxide 2003;9:64-76.

20. Chao J, Yu MS, Ho YS, Wang M, Chang RC. Dietary oxyresveratrol prevents parkinsonian mimetic 6hydroxydopamine neurotoxicity. Free Radical Biol Med 2008;45:1019-26.

21. Jeon SY, Kwon SH, Seong YH, Bae K, Hur JM, Lee YY, et al.Betasecretase (BACE1)-inhibiting stilbenoids from Smilax rhizoma. Phytomedicine 2007;14:403-8.
22. Breuer C, Wolf G, Andrabi SA, Lorenz P, Horn TF. Blood-brain barrier permeability to the neuroprotectant oxyresveratrol. Neurosci Lett 2006;393:113-8.

23. Yamchuen $P$, Jeenapongsa $R$, Nudmamud-Thanoi $S$, Limpeanchob N. Low-density lipoprotein increases amyloid precursor protein processing to theamyloidogenic pathway in differentiated SH-SY5Y cells. Biologia 2017;72:238-44.

24. Yamchuen $\mathrm{P}$, Chaiwiang $\mathrm{N}$, Lapphanichayakool $\mathrm{P}$, Ingkaninan $\mathrm{K}$, Limpeanchob N. Neuroprotective effect of Bacopa monnieri extract on oxidized low-density lipoprotein-induced neurotoxicity in SH-SY5Y neuroblastoma cells. Thai J Pharmacol 2017;39:5-18.

25. Ansari R, Perween Q, Kumar G, Jayanand, Rai DV. Effect of butylated hydroxyanisole on hydrogen peroxide-induced oxidative stress on cerebral glioma cell line. Asian J Pharm Clin Res 2014;7:177-80.

26. Bangaruswamy D, Jambunathan S, RPP Sundaravadivelu S. Prosopis cineraria leaf extract protect $\mathrm{H}_{2} \mathrm{O}_{2}$ induced oxidative stress-induced cell death in Saccharamyces cerevisiae. Asian J Pharm Clin Res 2015;8:311-5.

27. Li JM, Zhou H, Cai Q, Xiao GX. Role of mitochondrial dysfunction in hydrogen peroxide-induced apoptosis of intestinal epithelial cells. World J Gastroenterol 2003;9:562-7.

28. Zhou Y, Wang Q, Mark Evers B, Chung DH. Oxidative stressinduced intestinal epithelial cell apoptosis is mediated by p38 MAPK. Biochem Biophys Res Commun 2006;350:860-5.

29. Alvariño R, Alonso E, Tribalat MA, Gegunde S, Thomas OP, Botana LM. Evaluation of the protective effects of sarains on H2O2-induced mitochondrial dysfunction and oxidative stress in SH-SY5Y neuroblastoma cells. Neurotox Res 2017;32:368-80.

30. Tatsumi T, Kako KJ. Effects of hydrogen peroxide on mitochondrial enzyme function studied in situ in rat heart myocytes. Basic Res Cardiol 1993;88:199-211.

31. Fransen M, Nordgren M, Wang B, Apanasets 0 . Role of peroxisomes in ROS/RNS-metabolism: implications for human disease. Biochim Biophys Acta 2012;1822:1363-73.

32. Guo C, Sun L, Chen X, Zhang D. Oxidative stress, mitochondrial damage and neurodegenerative diseases. Neural Regen Res 2013;8:2003-14.

33. Chen W. Oxyresveratrol: a bioavailable dietary polyphenol. J Funct Foods 2016;22:122-31

34. Kambayashi Y, Binh NT, Asakura HW, Hibino Y, Hitomi Y, Nakamura $\mathrm{H}$, et al. Efficient assay for total antioxidant capacity in human plasma using a 96-well microplate. J Clin Biochem Nutr 2009;44:46-51.

35. Choi HY, Lee JH, Jegal KH, Cho IJ, Kim YW, Kim SC. Oxyresveratrol abrogates oxidative stress by activating ERKNrf2 pathway in the liver. Chem Biol Interact 2016;245:110-21.

36. Kalyanaraman B, Darley-Usmar V, Davies KJ, Dennery PA, Forman HJ, Grisham MB, et al. Measuring reactive oxygen and nitrogen species with fluorescent probes: challenges and limitations. Free Radical Biol Med 2012;52:1-6.

37. Hamad I, Arda N, Pekmez M, Karaer S, Temizkan G. Intracellular scavenging activity of Trolox (6-hydroxy-2,5,7,8tetramethylchromane-2-carboxylic acid) in the fission yeast, Schizosaccharomyces pombe. J Nat Sci Biol Med 2010;1:16-21. 